\title{
Remarkable Structure Deformation in Phenothiazine Trimer Radical Cation
}

Toshihiro Okamoto, Masato Kuratsu, Masatoshi Kozaki, Ken Hirotsu, Akio Ichimura, Toshio Matsushita, and Keiji Okada
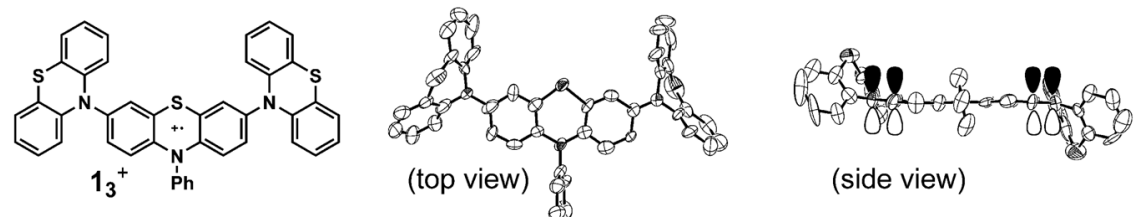

\section{Synthetic procedure}

\section{0-Boc-3,7-dibromophenothiazine (3):}

A mixture of $(\mathrm{Boc})_{2} \mathrm{O}(1.48 \mathrm{~g}, 6.8 \mathrm{mmol}, 1.2$ equiv), dimethylaminopyridine (68 mg, $0.56 \mathrm{mmol}$, 0.1 equiv), 2 (2.0 g, $5.6 \mathrm{mmol})$, and dry acetonitrile $(11 \mathrm{~mL})$ was refluxed for $24 \mathrm{~h}$ under nitrogen atmosphere. After cooling to room temperature, the mixture was poured into water and extracted with ethyl acetate. The organic layer was dried over sodium sulfate and evaporated under reduced pressure. The crude products were purified by alumina column chromatography eluted with toluene to yield $\mathbf{3}$ as a colorless powder $(2.53 \mathrm{~g}, 99 \%)$. The powder was recrystallized from acetonitrile.

3: colorless needles; mp 156.5-158.0 ${ }^{\circ} \mathrm{C},{ }^{1} \mathrm{H}$ NMR (300 MHz, $\left.\mathrm{CDCl}_{3}\right) \delta 1.48(\mathrm{~s}, 9 \mathrm{H}), 7.37-7.38(\mathrm{~m}, 4 \mathrm{H})$, 7.468-7.475 (m, 2H); ${ }^{13} \mathrm{C}$ NMR (100 MHz, $\left.\mathrm{C}_{6} \mathrm{D}_{6}\right) \delta 28.09,82.87,119.36,128.34,129.84,129.88,133.50$, 137.59, 151.80; IR (KBr, cm $\left.{ }^{-1}\right)$ 2982, 2932, 1709, 1568, 1462, 1367, 1331, 1254, 1234, 1163, 1144, 1076, 1024, 953, 812; MS (FAB) $m / z 457\left(\mathrm{M}^{+}\right)$; Anal. Calcd. for $\mathrm{C}_{17} \mathrm{H}_{15} \mathrm{Br}_{2} \mathrm{NO}_{2} \mathrm{~S}: \mathrm{C}$ 44.66, H 3.31, N 3.06, Found C 44.80, H 3.21, N 3.03. 


\section{0-Boc-3,7-di(phenothiazin-10-yl)phenothiazine (5)}

To a two-necked flask containing 3 (3.0 g, $6.7 \mathrm{mmol})$, phenothiazine (2.67 g, $13.4 \mathrm{mmol})$, $\operatorname{Pd}(\mathrm{dba})_{2}(161 \mathrm{mg}, 0.280 \mathrm{mmol})$, and sodium $t$-butoxide $(2.21 \mathrm{~g}, 23.1 \mathrm{mmol})$ were added a solution of tri-t-butylphosphine in $o$-xylene $[0.0525 \mathrm{M}](4.5 \mathrm{~mL})$ and $35 \mathrm{~mL}$ of anhydrous toluene under argon atmosphere. The mixture was refluxed for $90 \mathrm{~min}$. The hot reaction mixture was filtered in order to remove insoluble solids. The filtrate was concentrated under reduced pressure to give $\mathbf{5}$ as a yellow powder. The powder was recrystallized from a toluene-hexane mixture (87\%).

5: colorless needles; mp (decomp.) $212{ }^{\circ} \mathrm{C} ;{ }^{1} \mathrm{H}$ NMR (300 MHz, $\left.\mathrm{CDCl}_{3}\right) \delta 1.57$ (s, 9H), 6.40 (dd, 4H, $J=$ 8.1 Hz, 1.4 Hz), 6.83-6.95 (m, 8H), 7.07 (dd, 4H, $J=7.3 \mathrm{~Hz}, 1.7 \mathrm{~Hz}), 7.31(\mathrm{dd}, 2 \mathrm{H}, J=8.4,2.4 \mathrm{~Hz}), 7.37$ $(\mathrm{d}, 2 \mathrm{H}, J=2.4 \mathrm{~Hz}), 7.73(\mathrm{~d}, 2 \mathrm{H}, J=8.6 \mathrm{~Hz}) ;{ }^{13} \mathrm{C} \mathrm{NMR}\left(75 \mathrm{MHz}, \mathrm{CDCl}_{3}\right) \delta 28.18,82.91,117.15,121.74$, $123.05,125.28,126.93,127.00,127.95,128.05,128.20,128.92,129.02,133.90,137.58,139.38,143.66$, 152.17; IR (KBr, cm $\left.{ }^{-1}\right)$ 3063, 2976, 1719, 1580, 1477, 1462, 1443, 1393, 1367, 1306, 1258, 1234, 1155, 1043, 1024, 926, 745; HRMS (FAB) $m / z$ Calcd for $\mathrm{C}_{41} \mathrm{H}_{31} \mathrm{~N}_{3} \mathrm{O}_{2} \mathrm{~S}_{3}: 693.1578$, Found 693.1573.

\section{3,7-Di(phenothiazin-10-yl)phenothiazine (4)}

The compound 5 (2.0 g, $2.88 \mathrm{mmol})$ was dissolved in acetic acid $(60 \mathrm{~mL})$ and the solution was refluxed for $11 \mathrm{~h}$. After cooling to room temperature, the reaction mixture was poured into an ice bath and the solution was neutralized by addition of sodium hydroxide solution $(10 \%)$ with cooling. The mixture was extracted with chloroform. The chloroform layer was washed with distilled water, dried, and evaporated under reduced pressure. The crude product was purified by alumina column chromatography eluted with a chloroform-toluene $(1: 1)$ to yield 4 as a colorless powder $(1.610 \mathrm{~g}, 94 \%)$. 
4: colorless powder; mp (decomp.) $280{ }^{\circ} \mathrm{C},{ }^{1} \mathrm{H}$ NMR (400 MHz, DMSO-d 6 ) $\delta 6.28$ (d, 4H, J=8.3 Hz), $6.84(\mathrm{t}, 4 \mathrm{H}, J=7.7 \mathrm{~Hz}), 6.93-7.10(\mathrm{~m}, 14 \mathrm{H}), 9.21(\mathrm{~s}, 1 \mathrm{H})$; IR $\left(\mathrm{KBr}, \mathrm{cm}^{-1}\right) 3358,3059,1717,1593,1570$, 1460, 1441, 1310, 1263, 1236, 1126, 1042, 922, 818, 743, 623; HRMS (FAB) $m / z$ Calcd. for $\mathrm{C}_{36} \mathrm{H}_{23} \mathrm{~N}_{3} \mathrm{~S}_{3}$ : 593.1054, Found 593.1045.

\section{0-Phenyl-3,7-di(phenothiazine-10-yl)phenothiazine $\left(1_{3}\right)$}

To a two-necked flask containing 4 (1.0 g, $1.68 \mathrm{mmol})$, bromobenzene (290 mg, $1.85 \mathrm{mmol})$, $\mathrm{Pd}(\mathrm{dba})_{2}(17.4 \mathrm{mg}, 0.030 \mathrm{mmol})$, and sodium $t$-butoxide $(242 \mathrm{mg}, 2.52 \mathrm{mmol})$ were added a solution of tri-t-butylphosphine in $o$-xylene $[0.0525 \mathrm{M}](0.48 \mathrm{~mL})$ and $20 \mathrm{~mL}$ of anhydrous toluene under argon atmosphere. The suspension was refluxed for $30 \mathrm{~min}$. The hot reaction mixture was filtered in order to remove insoluble materials. The filtrate was concentrated under reduced pressure. The crude product was purified by alumina column chromatography eluted with a toluene-hexane $(1: 1)$ to give $\mathbf{1}_{3}$ as a yellow powder $(1.12 \mathrm{~g}, 100 \%)$. The powder was recrystallized from a mixed solvent of dichloromethane-ethanol.

13: yellow needles; mp 277.0-279.0 ${ }^{\circ} \mathrm{C} ;{ }^{1} \mathrm{H}$ NMR (400 MHz, $\left.\mathrm{C}_{6} \mathrm{D}_{6}\right) \delta 6.19(\mathrm{~d}, 2 \mathrm{H}, J=8.8 \mathrm{~Hz}), 6.27(\mathrm{~d}, 4 \mathrm{H}$, $J=7.3 \mathrm{~Hz}), 6.51(\mathrm{dd}, 2 \mathrm{H}, J=8.8,2.4 \mathrm{~Hz}), 6.56-6.64(\mathrm{~m}, 9 \mathrm{H}), 6.73(\mathrm{~d}, 2 \mathrm{H}, J=2.2 \mathrm{~Hz}), 6.92(\mathrm{dd}, 4 \mathrm{H}, J=$ 7.1 Hz, 1.7 Hz), 7.01-7.11 (m, 4H); IR (KBr, cm $\left.{ }^{-1}\right)$ 1595, 1570, 1460, 1441, 1298, 1259, 1234, 1128, 1119, 1043, 924, 745, 698, 669, 546; HRMS (FAB) $m / z$ Calcd. for $\mathrm{C}_{42} \mathrm{H}_{27} \mathrm{~N}_{3} \mathrm{~S}_{3}$ : 669.1367, Found 669.1382.

\section{0-Phenyl-3,7-di(phenothiazine-10-yl)phenothiazine radical cation $\left(1_{3}^{+} \cdot \mathrm{PF}_{6}^{-} \cdot 0.5 \mathrm{CH}_{3} \mathrm{CN}\right)$}

The following procedure was performed in a glove box. To a solution of $\mathbf{1}_{\mathbf{3}}(300 \mathrm{mg})$ in ca. $20 \mathrm{ml}$ of dry $\mathrm{CH}_{2} \mathrm{Cl}_{2}$, a mixture of $\mathrm{PhI}(\mathrm{OAc})_{2}(72 \mathrm{mg})$ and $\mathrm{CF}_{3} \mathrm{SO}_{3} \mathrm{H}(67 \mathrm{mg})$ in $\mathrm{CH}_{2} \mathrm{Cl}_{2}$ (ca $3 \mathrm{ml}$ ) was added dropwise 
and stirred for $20 \mathrm{~min}$ at room temperature. The solvent was then evaporated to ca. $5 \mathrm{ml}$ of volume. Addition of ca. $20 \mathrm{ml}$ of ether to the reaction mixture gave brown precipitates $\left(\mathbf{1}_{3}{ }^{+} \cdot \mathrm{CF}_{3} \mathrm{SO}_{3}{ }^{-} ; 294 \mathrm{mg}\right.$, $80 \%)$. The obtained $\mathbf{1}_{3}{ }^{+} \cdot \mathrm{CF}_{3} \mathrm{SO}_{3}{ }^{-}(60 \mathrm{mg})$ was dissolved in ca. $2 \mathrm{ml}$ of $\mathrm{CH}_{3} \mathrm{CN}$. To the $\mathrm{CH}_{3} \mathrm{CN}$ solution, a solution of $\mathrm{TBA}^{+} \cdot \mathrm{PF}_{6}^{-}(28 \mathrm{mg})$ in ca. $1 \mathrm{ml} \mathrm{CH}{ }_{3} \mathrm{CN}$ was added, and the solvent was slowly evaporated in the glove box. After five days, black plates were obtained (37 mg, $62 \%$ yield).

$\mathbf{1}_{3}^{+} \cdot \mathrm{PF}_{6} \cdot 0.5 \mathrm{CH}_{3} \mathrm{CN}$ : black plates, $\mathrm{mp}$ (decomp. $)$ ca. $257^{\circ} \mathrm{C}$; EPR $g=2.0041\left(v_{0}=9.2455\right.$ broad three lines with $a_{\mathrm{N}}=0.55 \mathrm{mT}$ in butyronitrile at room temperature); IR $\left(\mathrm{KBr}, \mathrm{cm}^{-1}\right) 1595,1568,1473,1460,1444$, 1280, 1263, 1246, 1164, 1128, 1076, 1031, 842, 766, 734, 698, 669, 637, 557; MS (FAB) 669.1; Anal. Calcd. for $\mathbf{1}_{3}{ }^{+} \cdot \mathrm{PF}_{6} \cdot 0.5 \mathrm{CH}_{3} \mathrm{CN}$ : C 61.82, H 3.44, N 5.87, Found C 62.01, H 3.33, N 5.90. 